\title{
EFFECT OF CHITOSAN AND POTASSIUM PERMANGANATE TREATMENTS ON QUALITY AND STORABILITY OF CANTALOUPE FRUITS
}

\author{
RAGAB, M. E. ${ }^{1}$, A. ABOU EL-YAZIED', \\ M. S. EMAM ${ }^{2}$ and M. M. HAFFEZ ${ }^{2}$
}

1. Dept. of Hort., Fac. of Agric., Ain Shams Univ., Cairo, Egypt.

2. Dept. of Vegetable Handling, Hort. Res. Institute, Agric. Res. Center, Giza, Egypt.

(Manuscript received 22 October 2018)

\begin{abstract}
$\mathrm{T}$ his study was carried out on cantaloupe fruits (Cucumis melo L. cv. Gal 152, Galia type) harvested at yellow green color stage in the winter of 2013 and 2014 seasons from a private farm at EL-Ismailia Governorate, to evaluate the effects of chitosan at 1000 and 2000 ppm, potassium permanganate sachets contained 2.5 and $5 \mathrm{~g}$ per box and distillate water (control) on maintaining quality and storability of cantaloupe fruits during storage at $5{ }^{\circ} \mathrm{C}$ and $95 \%$ relative humidity for 28 days in addition to 2 days at $10^{\circ} \mathrm{C}$ (shelf life conditions). Results showed that all postharvest treatments reduced weight loss \%, the loss of TSS\%, L. ascorbic acid and total sugars, had the higher values of firmness and general appearance as compared with untreated control during storage and shelf life condition. Cantaloupe fruits soaked in chitosan at 2000 ppm or packed with $5 \mathrm{~g}$ potassium permanganate were the most effective treatments in this concern and gave fruits with good appearance after 21 days at $5^{\circ} \mathrm{C}$ plus 2 days at $10^{\circ} \mathrm{C}$. The lower concentrations of these materials were less effective treatments in this concern.

Keywords: Cantaloupe fruits; chitosan; potassium permanganate; total sugars; firmness; L. ascorbic acid; quality; storability.
\end{abstract}

\section{INTRODUCTION}

Cantaloupe (Cucumis melo var. Reticulatus) is a climacteric fruit and favorable to consumers. Its ripening is highly coordinated by ethylene (Seymour et al., 1993). Galia are premium melons consumption with excellent flavor and intense aroma, however, the storage life of the fruit harvested pre ripe is 2 to 3 weeks even at low temperatures at 5 to $6^{\circ} \mathrm{C}$ (Fallik et al., 2001).

Climacteric fruits such as cantaloupe could reduce the postharvest life by accelerating ripening if they exposure to ethylene (Reid, 1985). To maintaining fruit quality and improve storability and extend the shelf life of cantaloupe fruit, chitosan and potassium permanganate were used as postharvest treatments in conjunction with low temperature.

Chitosan one of successfully edible coating material on food surface without compromising the tasting, so chitosan used by effectively to extend the shelf life of product. The chitosan films are used as coating of fresh fruits and vegetables (apples, oranges, tomato, pepper, cantaloupe ...etc.) because they are flexible, offer valuable 
properties such as elasticity, selective permeability and act as antimicrobial barrier against pathogens (Hussein et al., 2015). Also chitosan has positive effect of coating that it could to extend the storage life of fruits and vegetables. Chitosan has a semi permeable film that regulates the gas exchange and reduces transpiration and slow down ripening of fruits. Also, respiration rate and hence water loss are reduced (Bautista - Banos et al. 2006). This effect has been reported by Chong et al. 2015 in honeydew melon.

Potassium permanganate reduces or removes the ethylene of the storage environment, by oxidizing the ethylene produced by the fruit during ripening, extending the pre climacteric period and the postharvest life. Easy appliance and low price are the benefits of using potassium permanganate (Klein and lurie, 1992).

The objective of this work was to investigate the potential of some postharvest treatments on quality and storability of cantaloupe fruits (chitosan and potassium permanganate) individually in different concentrations to extend shelf life and maintain quality of cantaloupe fruits during storage and shelf life conditions.

\section{MATERIALS AND METHODES}

Cantaloupe plants (Cucumis melo L. cv. Gal 152, Galia type) were grown under plastic tunnels condition in a private farm at EL-Ismaillia governorate in the winter season of 2013 and 2014. Fruits were harvested at yellow green color stage (color stage 3) according to Fallik et al. (2001) on May 3 and 7 in 2013 and 2014 seasons, respectively. Then transported to laboratory of Handling of Vegetable Crops, Department, Horticulture Research Institute, Giza Governorate and were selected with uniformity of size, color and free of visual damage or defects. The fruits were washed and surface-sterilized in $200 \mathrm{ppm}$ sodium hypochlorite solution for $5 \mathrm{~min}$, rinsed and air dried in a well-ventilated room. The fruits were treated with the following five treatments:

1- Soaking in chitosan at $1000 \mathrm{ppm}$ for 3 minutes.

2- Soaking in chitosan at 2000 ppm for 3 minutes.

3- Potassium permanganate sachets contained $2.5 \mathrm{~g}$ per box.

4- Potassium permanganate sachets contained $5 \mathrm{~g}$ per box.

5- Control (soaking in distilled water for 3 minutes).

All samples of cantaloupe fruits were air dried, placed in carton box $(33 \mathrm{~cm}$ $x 23 \mathrm{~cm} \times 12.5 \mathrm{~cm}$ ) contained three fruits and wrapped with polypropylene film for all treatments, each box represented as one experimental unit. Twelve experimental units were made for each treatment and stored at $5{ }^{\circ} \mathrm{C}$ and $95 \%$ relative humidity for 28 days. A complete randomized design was adopted. Three replicates from each treatment were taken at random and examined immediately after treatment and every 
7 days at $5{ }^{\circ} \mathrm{C}$ in addition to 2 days at $10^{\circ} \mathrm{C}$ (shelf life conditions) for the following properties: weight loss percentage, general appearance, fruit firmness, total soluble solids, total sugar and L. ascorbic acid content.

\section{Preparation of edible coating solution:}

Chitosan is a commercial product, it includes chitosan at 90-95\%. (2-Amino-2deoxy-beta-D-glucosamine). Chitosan was bought from El-Gomhouria chemical Company, Egypt. Chitosan coating at (1000 or 2000 ppm) was prepared by dissolving $1 \mathrm{~g}$ or $2 \mathrm{~g}$ chitosan powder in $1000 \mathrm{ml}$ of distilled water, respectively and homogenized by magnetic stirrer. Glycerol $(1.5 \% \mathrm{~W} / \mathrm{V})$ was added into the mixture as a plasticizer.

\section{Quality attributes:}

\section{1- Weight loss percentage:}

It was estimated according to the equation:

Initial weight of fruits - weight at fruits at sampling date

Weight loss percentage $=$ $x 100$

Initial weight

2- General appearance (GA): was evaluated using scale from 9-1, where $9=$ excellent, 7 =good, 5 =fair, 3 = poor, 1 =unsalable as described by Kader et al. (1973).

3- Firmness: Fruit firmness was determined at the two positions on each fruit using a firmness tester, (Pressure Tester) with an $8 \mathrm{~mm}$ plunger.

4- Total soluble solids: Total soluble solids were determined from the fresh materials by using PR- 101 digital refractometer.

5- Total sugar: Total sugar was determined in fresh cut cantaloupe by using Lane and Eynon method according to AOAC (2000).

6- L. Ascorbic acid: Ascorbic acid was determined by titration method using 2.6 dichloro-phenol indo-phenols as described in AOAC (1990).

\section{Statistical Analysis:}

The experiment was factorial with 2 factors (tested treatments and storage periods) distributed in complete randomized design (CRD) with 3 replicates. Comparison between means was evaluated by Duncan's Multiple Range Test at 5\% level of significance. The statistical analysis was performed according to Sendecor and Cochran (1982).

\section{RESULTS AND DISCUSSION}

\section{1- Weight loss percentage}

Data in Tables (1\&2) demonstrate that weight loss percentage of cantaloupe fruits increased considerably and consistently with the prolongation of storage period. 
These results were true in the two seasons. Similar results were reported by Atress and Attia (2011) on cantaloupe fruits. The weight loss is natural consequence of the catabolism of horticulture products, the weight loss may be related to respiration and metabolic processes during storage as reported by Watada and Qi (1999).

Table 1. Effect of chitosan and potassium permanganate treatments on weight loss (\%) of cantaloupe fruits during cold storage at $5^{\circ} \mathrm{C}$ and $95 \% \mathrm{RH}$ in 2013 and 2014 seasons.

\begin{tabular}{|c|c|c|c|c|c|c|}
\hline \multirow{2}{*}{ Treatments } & \multicolumn{6}{|c|}{ Storage period (day) } \\
\hline & 0 & 7 & 14 & 21 & 28 & Mean \\
\hline \multicolumn{7}{|c|}{ First season (2013) } \\
\hline Chitosan (1000 ppm) & $0.00 n$ & $1.35 \mathrm{k}$ & 2.281 & 3.44 ef & $5.80 \mathrm{a}$ & $2.57 \mathrm{C}$ \\
\hline Chitosan (2000 ppm) & $0.00 n$ & $0.88 \mathrm{Im}$ & $1.14 \mathrm{kl}$ & $2.62 \mathrm{~h}$ & $4.62 \mathrm{c}$ & $1.85 \mathrm{E}$ \\
\hline $\mathrm{KMnO}_{4}(2.5 \mathrm{~g})$ & $0.00 n$ & $0.85 \mathrm{~m}$ & $3.30 \mathrm{f}$ & $4.47 \mathrm{~cd}$ & $5.16 b$ & $2.76 \mathrm{~B}$ \\
\hline $\mathrm{KMnO}_{4}(5 \mathrm{~g})$ & $0.00 n$ & $1.30 \mathrm{k}$ & $1.71 \mathrm{j}$ & $2.95 \mathrm{~g}$ & $4.30 \mathrm{~d}$ & $2.05 \mathrm{D}$ \\
\hline Control & $0.00 n$ & $1.94 \mathrm{j}$ & $3.64 \mathrm{e}$ & $4.68 \mathrm{c}$ & $6.05 \mathrm{a}$ & $3.26 \mathrm{~A}$ \\
\hline \multirow[t]{2}{*}{ Mean } & $0.00 \mathrm{E}$ & $1.26 \mathrm{D}$ & $2.41 \mathrm{C}$ & $3.63 \mathrm{~B}$ & $5.19 \mathrm{~A}$ & \\
\hline & \multicolumn{5}{|c|}{ Second season (2014) } & \\
\hline Chitosan (1000 ppm) & $0.00 n$ & $1.91 \mathrm{j}$ & $2.61 \mathrm{i}$ & $3.01 \mathrm{~h}$ & $5.26 b c$ & $2.56 \mathrm{~B}$ \\
\hline Chitosan (2000 ppm) & $0.00 n$ & 0.771 & $1.26 \mathrm{k}$ & $3.64 \mathrm{fg}$ & $5.02 c$ & $1.14 \mathrm{D}$ \\
\hline $\mathrm{KMnO}_{4}(2.5 \mathrm{~g})$ & $0.00 n$ & $0.35 \mathrm{~m}$ & $2.15 \mathrm{j}$ & $4.31 \mathrm{~d}$ & $5.12 b c$ & $2.38 \mathrm{C}$ \\
\hline $\mathrm{KMnO}_{4}(5 \mathrm{~g})$ & $0.00 n$ & $1.07 \mathrm{k}$ & $2.10 \mathrm{j}$ & 3.90 ef & $4.07 \mathrm{de}$ & $2.23 \mathrm{C}$ \\
\hline Control & $0.00 n$ & $2.06 \mathrm{j}$ & $3.47 \mathrm{~g}$ & $5.40 \mathrm{~b}$ & 7.67 a & $3.72 \mathrm{~A}$ \\
\hline Mean & $0.00 \mathrm{E}$ & $1.23 \mathrm{D}$ & $2.32 \mathrm{C}$ & 4.05 B & $5.43 \mathrm{~A}$ & \\
\hline
\end{tabular}

Means with the same capital letters in the same column or row are not significantly different at $\mathrm{P} \leq 0.05$ level; Tukey's multiple range test and the small letters for interaction.

Table 2. Effect of chitosan and potassium permanganate treatments on weight loss (\%) of cantaloupe fruits during storage at $5^{\circ} \mathrm{C}$ plus 2 days shelf life at $10^{\circ} \mathrm{C}$ in 2013 and 2014 seasons.

\begin{tabular}{|c|c|c|c|c|c|c|}
\hline \multirow{2}{*}{ Treatments } & \multicolumn{6}{|c|}{ Storage period and shelf life (day) } \\
\hline & 0 & $7+2$ days & 14+2days & $21+2$ days & $28+2$ days & Mean \\
\hline \multicolumn{7}{|c|}{ First season (2013) } \\
\hline Chitosan (1000 ppm) & 0.001 & $2.14 j$ & $3.55 \mathrm{~h}$ & $4.58 \mathrm{f}$ & $6.11 \mathrm{~cd}$ & $3.28 \mathrm{C}$ \\
\hline Chitosan (2000 ppm) & 0.001 & $1.64 \mathrm{k}$ & $2.58 \mathrm{i}$ & $3.80 \mathrm{~h}$ & $5.50 \mathrm{e}$ & $2.70 \mathrm{E}$ \\
\hline $\mathrm{KMnO}_{4}(2.5 \mathrm{~g})$ & $0.00 \mathrm{I}$ & $2.82 \mathrm{i}$ & $4.17 \mathrm{~g}$ & $5.84 \mathrm{~d}$ & $7.62 b$ & $4.09 \mathrm{~B}$ \\
\hline $\mathrm{KMnO}_{4}(5 \mathrm{~g})$ & 0.001 & $1.95 \mathrm{j}$ & $2.80 \mathrm{i}$ & $4.26 \mathrm{~g}$ & $6.32 \mathrm{c}$ & $3.07 \mathrm{D}$ \\
\hline Control & 0.001 & $3.68 \mathrm{~h}$ & $5.24 \mathrm{e}$ & $7.34 \mathrm{~b}$ & $9.78 \mathrm{a}$ & $5.21 \mathrm{~A}$ \\
\hline Mean & $0.00 \mathrm{E}$ & $2.45 \mathrm{D}$ & $3.67 \mathrm{C}$ & $5.16 \mathrm{~B}$ & $7.07 \mathrm{~A}$ & \\
\hline \multicolumn{7}{|c|}{ Second season (2014) } \\
\hline Chitosan (1000 ppm) & $0.00 \mathrm{k}$ & $2.75 \mathrm{hi}$ & $3.50 \mathrm{~g}$ & $4.80 \mathrm{e}$ & $6.31 \mathrm{c}$ & $3.47 \mathrm{C}$ \\
\hline Chitosan (2000 ppm) & $0.00 \mathrm{k}$ & $1.75 \mathrm{j}$ & $2.80 \mathrm{~h}$ & $4.20 \mathrm{f}$ & $4.80 \mathrm{e}$ & $2.71 \mathrm{E}$ \\
\hline $\mathrm{KMnO}_{4}(2.5 \mathrm{~g})$ & $0.00 \mathrm{k}$ & $2.88 \mathrm{~h}$ & $3.83 \mathrm{~g}$ & $5.39 \mathrm{~d}$ & $7.45 b$ & $3.91 \mathrm{~B}$ \\
\hline $\mathrm{KMnO}_{4}(5 \mathrm{~g})$ & $0.00 \mathrm{k}$ & $2.03 j$ & $2.42 \mathrm{i}$ & 4.45 ef & $6.41 \mathrm{c}$ & $3.06 \mathrm{D}$ \\
\hline Control & $0.00 \mathrm{k}$ & $3.75 \mathrm{~g}$ & $5.18 \mathrm{~d}$ & $7.18 \mathrm{~b}$ & 8.99 a & $5.02 \mathrm{~A}$ \\
\hline Mean & $0.00 \mathrm{E}$ & $2.63 \mathrm{D}$ & $3.55 \mathrm{C}$ & $5.20 \mathrm{~B}$ & $6.79 \mathrm{~A}$ & \\
\hline
\end{tabular}

Means with the same capital letters in the same column or row are not significantly different at $P \leq 0.05$ level; Tukey's multiple range test and the small letters for interaction. 
Data revealed that the tested postharvest treatments had significantly effective on loss of weight during storage or shelf life. They reduced the loss in weight as compared with control. However, cantaloupe fruits soaked in chitosan at 2000 ppm or packed with 5 grams $(\mathrm{g})$ potassium permanganate were the most effective treatment in reducing the weight loss with significant differences between them in the two seasons during storage and shelf life, the control gave the highest values of weight loss. Similar results were obtained by Fard et al. (2010) for chitosan and Akbari and Rahemi (2004) for potassium permanganate.

The lowest weight loss from chitosan treatment is due to the semi permeable film on the fruit surface which formed by the chitosan, consequently modifying the internal atmosphere of the fruits with limited gas exchange due to the coating barrier, enzymatic activity and metabolism in evolving respiration can be thus affected, thereby resulting in lower weight loss (Raymond et al., 2012).

Minimizing weight loss of cantaloupe fruits during storage with potassium permanganate treatment may be due to that potassium permanganate removes ethylene from produce's atmosphere surrounding as potassium permanganate oxidizing it to ethylene glycol, which later turns to water and carbon dioxide (Sardabi et al., 2013)., which decreases respiration rate (Hao and Hao., 1993) and consequently reduces fresh weight loss. Also, Sammi and Masud (2007) found that potassium permanganate significantly delayed the onset of climacteric ethylene production and respiration rate in tomato fruits during storage, which diminished the weight loss in fruit during storage.

In general, the interaction show that cantaloupe fruits soaked in chitosan at $2000 \mathrm{ppm}$ or packed with $5 \mathrm{~g}$ potassium permanganate decreased weight loss percentage of fruits during all storage periods. On other hand, cantaloupe fruits soaked in chitosan at 1000 or $2000 \mathrm{ppm}$ or packed with $5 \mathrm{~g}$ potassium permanganate decreased weight loss during shelf life as compared to the other tested treatments.

\section{2- General appearance (GA)}

Data in Figs (1\&2) show that general appearance of cantaloupe fruits decreased significantly with prolonging of the storage period and this was true in two seasons. Such decrease in general appearance of fruits, mostly may be due to a slight dryness of the fruit surface, instead of translucency or macroscopic decay, as reported by Atress and Attia (2011). 
$1^{\text {st }}$ season

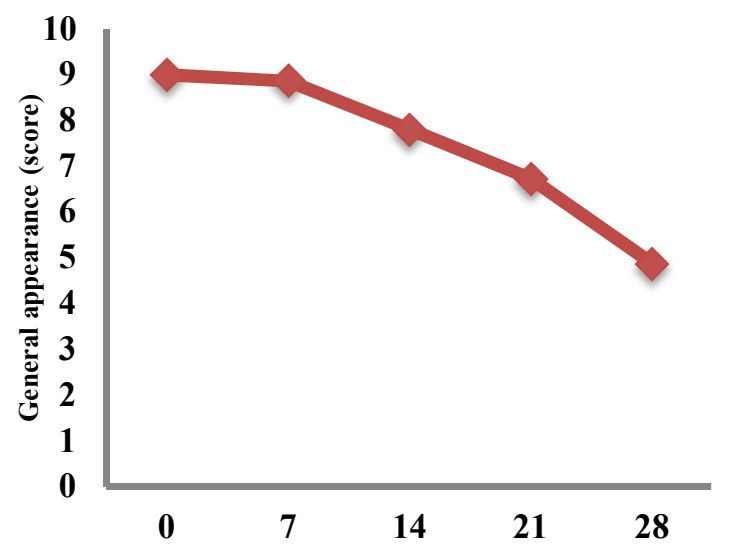

$$
2 \text { nd } \text { season }
$$

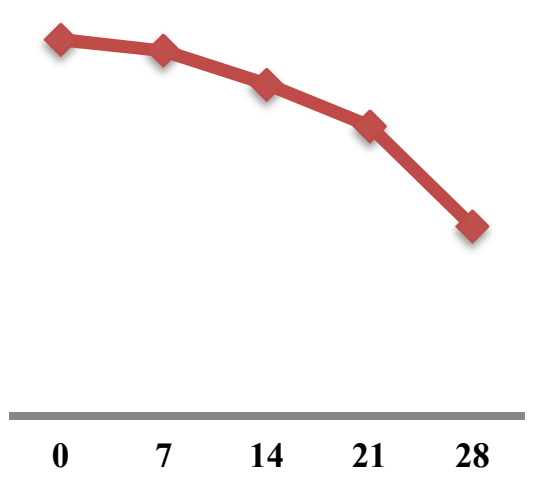

\section{Storage period (day)}

Fig. 1. Effect of storage period on general appearance (score) of cantaloupe fruits during storage at $5^{\circ} \mathrm{C}$ and $95 \% \mathrm{RH}$ in 2013 and 2014 seasons.

$1^{\text {st }}$ season

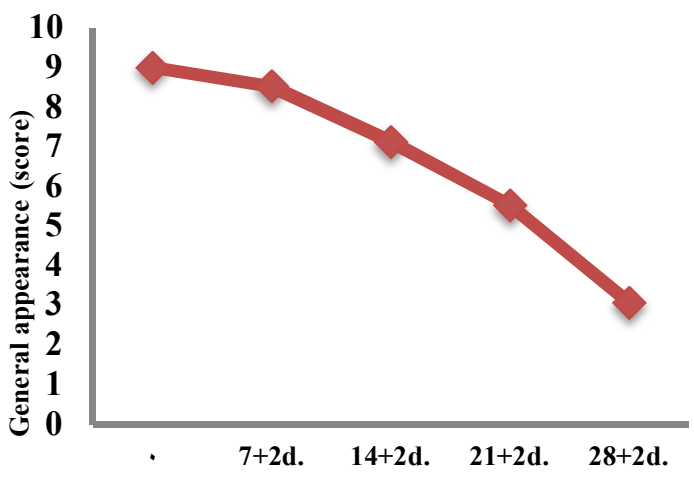

$2 \stackrel{\text { nd }}{\text { season }}$

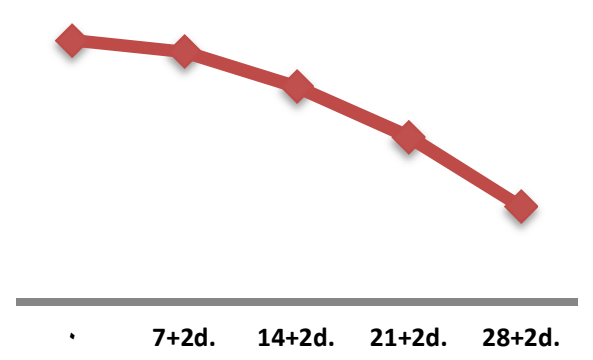

Fig. 2. Effect of storage period on general appearance (score) of cantaloupe fruits during storage at $5^{\circ} \mathrm{C}$ and $95 \% \mathrm{RH}$ plus 2 days shelf life at $10^{\circ} \mathrm{C}$ in 2013 and 2014 seasons.

Concerning the effect of postharvest treatments, data in Figs (3\&4) show that there were significant differences between postharvest treatments and control. Cantaloupe 
$1^{\text {st }}$ season

Chitosan (CH) $2^{\text {nd }}$ season

Potassium Permanganate $\left(\mathrm{KMnO}_{4}\right)$
A

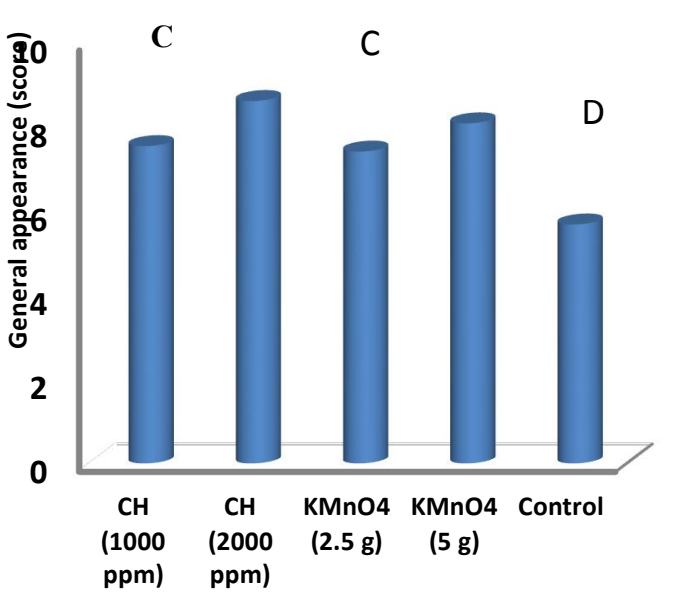

C A

D B

$E$

Treatments

Fig. 3. Effect of chitosan and potassium permanganate treatments on general appearance (score) of cantaloupe fruits at $5^{\circ} \mathrm{C}$ and $95 \% \mathrm{RH}$ in 2013 and 2014 seasons.

$1^{\text {st }}$ season

Chitosan (CH)

A

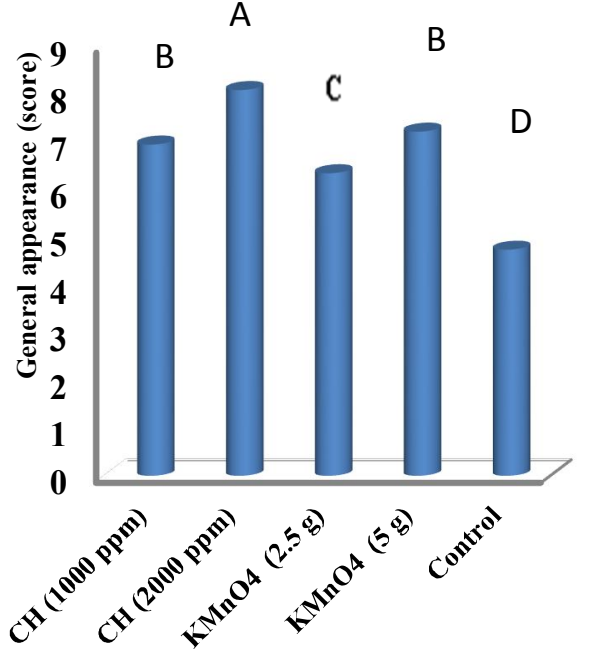

2 nd season

Potassium Permanganate $\left(\mathrm{KMnO}_{4}\right)$

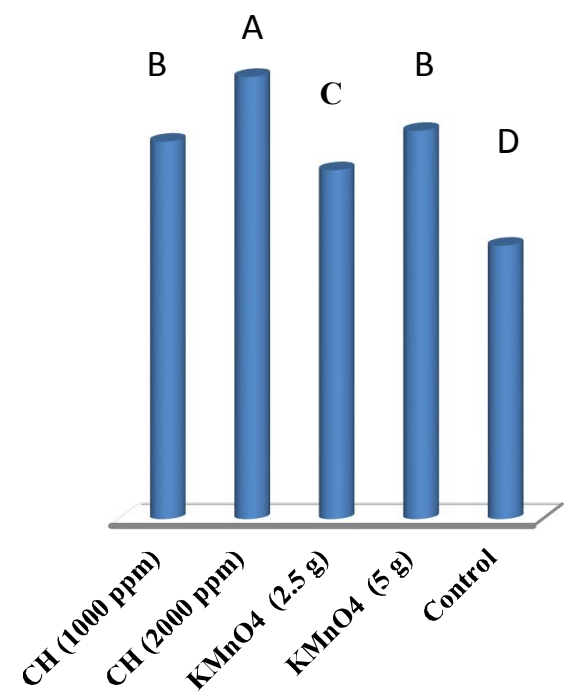

Treatments

Fig. 4. Effect of chitosan and potassium permanganate treatments on general appearance (score) of cantaloupe fruits during storage at $5^{\circ} \mathrm{C}$ plus 2 days shelf life at $10^{\circ} \mathrm{C}$ in 2013 and 2014 seasons. 
fruits treated with all treatments were better than control during storage or shelf life. During the storage at $5^{\circ} \mathrm{C}$ fruits soaked in chitosan at $2000 \mathrm{ppm}$ or packed with $5 \mathrm{~g}$ potassium permanganate were the most effective treatments for maintaining general appearance with significant difference between them during the storage in the two seasons. In another words, these treatments gave the highest scores of appearance, while control obtained the lowest ones in this concern.

Table 3. Effect of interaction between chitosan, potassium permanganate treatments and storage period on general appearance (score) of cantaloupe fruits during storage at $5^{\circ} \mathrm{C}$ and $95 \% \mathrm{RH}$ in 2013 and 2014 seasons.

\begin{tabular}{|c|c|c|c|c|c|}
\hline \multirow{2}{*}{ Treatments } & \multicolumn{5}{|c|}{ Storage period (day) } \\
\hline & $\mathbf{0}$ & 7 & 14 & 21 & 28 \\
\hline & \multicolumn{4}{|c|}{ First season (2013) } & \\
\hline Chitosan (1000 ppm) & $9.00 \mathrm{a}$ & $9.00 \mathrm{a}$ & $8.33 a b$ & $6.33 \mathrm{~d}$ & $5.00 \mathrm{e}$ \\
\hline Chitosan (2000 ppm) & $9.00 \mathrm{a}$ & $9.00 \mathrm{a}$ & $9.00 \mathrm{a}$ & $8.33 a b$ & $7.67 \mathrm{bc}$ \\
\hline $\mathrm{KMnO}_{4}(2.5 \mathrm{~g})$ & $9.00 \mathrm{a}$ & $9.00 \mathrm{a}$ & $7.67 \mathrm{bc}$ & $7.00 \mathrm{~cd}$ & 4.33 ef \\
\hline $\mathrm{KMnO}_{4}(5 \mathrm{~g})$ & $9.00 \mathrm{a}$ & $9.00 \mathrm{a}$ & $9.00 \mathrm{a}$ & $8.33 a b$ & $5.00 \mathrm{e}$ \\
\hline \multirow[t]{2}{*}{ Control } & $9.00 \mathrm{a}$ & $8.33 \mathrm{ab}$ & $5.00 \mathrm{e}$ & $3.67 \mathrm{f}$ & $2.33 \mathrm{~g}$ \\
\hline & \multicolumn{4}{|c|}{ Second season (2014) } & \\
\hline Chitosan (1000 ppm) & $9.00 \mathrm{a}$ & $9.00 \mathrm{a}$ & $8.33 a b$ & $7.67 \mathrm{bc}$ & $4.67 \mathrm{de}$ \\
\hline Chitosan (2000 ppm) & $9.00 \mathrm{a}$ & $9.00 \mathrm{a}$ & $9.00 \mathrm{a}$ & $8.33 a b$ & $7.00 \mathrm{c}$ \\
\hline $\mathrm{KMnO}_{4}(2.5 \mathrm{~g})$ & $9.00 \mathrm{a}$ & $9.00 \mathrm{a}$ & $7.67 \mathrm{bc}$ & $7.00 \mathrm{c}$ & 3.67 ef \\
\hline $\mathrm{KMnO}_{4}(5 \mathrm{~g})$ & $9.00 \mathrm{a}$ & $9.00 \mathrm{a}$ & $9.00 \mathrm{a}$ & $8.33 a b$ & $5.00 \mathrm{~d}$ \\
\hline Control & $9.00 \mathrm{a}$ & $7.67 \mathrm{bc}$ & $5.67 \mathrm{~d}$ & $3.33 \mathrm{fg}$ & $2.33 \mathrm{~g}$ \\
\hline
\end{tabular}

Values with the same letters are not significantly different at $P \leq 0.05$ level; Tukey's multiple range test.

Cantaloupe fruits soaked in chitosan at $1000 \mathrm{ppm}$ or packed with $2.5 \mathrm{~g}$ potassium permanganate were less effective in maintaining general appearance when compared with the other treatments. During shelf life conditions, fruits soaked in chitosan at 2000 ppm followed by chitosan at 1000 ppm or packed with $5 \mathrm{~g} \mathrm{KMnO}_{4}$ gave the highest scores of appearance. However, coating cantaloupe fruits with chitosan at $2000 \mathrm{ppm}$ was the most effective treatment for maintaining general appearance during shelf life in the two seasons. These results were in agreement with those reported by Hernandez-Munoz et al. (2008) for chitosan and Sardabi et al. (2013) for potassium permanganate. 
Table 4. Effect of interaction between the tested postharvest treatments and storage period on general appearance (score) of cantaloupe fruits during storage at $5^{\circ} \mathrm{C}$ plus 2 days shelf life at $10^{\circ} \mathrm{C}$ in 2013 and 2014 seasons.

\begin{tabular}{|c|c|c|c|c|c|}
\hline \multirow{2}{*}{ Treatments } & \multicolumn{5}{|c|}{ Storage period and shelf life (day) } \\
\hline & $\mathbf{0}$ & 7+2day & 14+2day & 21+2day & 28+2day \\
\hline & \multicolumn{4}{|c|}{ Frist season (2013) } & \\
\hline Chitosan (1000 ppm) & $9.00 \mathrm{a}$ & $9.00 \mathrm{a}$ & 7.67 bc & $5.33 \mathrm{~d}$ & $3.67 \mathrm{e}$ \\
\hline Chitosan (2000 ppm) & $9.00 \mathrm{a}$ & $9.00 \mathrm{a}$ & $9.00 \mathrm{a}$ & $7.67 \mathrm{bc}$ & $5.67 \mathrm{~d}$ \\
\hline $\mathrm{KMnO}_{4}(2.5 \mathrm{~g})$ & $9.00 \mathrm{a}$ & $8.33 a b$ & $7.00 \mathrm{c}$ & $5.00 \mathrm{~d}$ & $2.33 \mathrm{f}$ \\
\hline $\mathrm{KMnO}_{4}(5 \mathrm{~g})$ & $9.00 \mathrm{a}$ & $9.00 \mathrm{a}$ & $8.33 \mathrm{ab}$ & $7.00 \mathrm{c}$ & 2.67 ef \\
\hline \multirow{2}{*}{ Control } & $9.00 \mathrm{a}$ & 7.33 bc & $3.67 \mathrm{e}$ & 2.67 ef & $1.00 \mathrm{~g}$ \\
\hline & \multicolumn{4}{|c|}{ Second season (2014) } & \\
\hline Chitosan (1000 ppm) & $9.00 \mathrm{a}$ & $9.00 \mathrm{a}$ & $7.67 \mathrm{a}-\mathrm{c}$ & $5.67 \mathrm{de}$ & $3.67 \mathrm{fg}$ \\
\hline Chitosan (2000 ppm) & $9.00 \mathrm{a}$ & $9.00 \mathrm{a}$ & $9.00 \mathrm{a}$ & $7.67 \mathrm{a}-\mathrm{c}$ & $6.33 c-e$ \\
\hline $\mathrm{KMnO}_{4}(2.5 \mathrm{~g})$ & $9.00 \mathrm{a}$ & $9.00 \mathrm{a}$ & $7.00 \mathrm{~b}-\mathrm{d}$ & 5.00 ef & $2.33 \mathrm{gh}$ \\
\hline $\mathrm{KMnO}_{4}(5 \mathrm{~g})$ & $9.00 \mathrm{a}$ & $9.00 \mathrm{a}$ & $8.33 a b$ & $7.00 \mathrm{~b}-\mathrm{d}$ & $2.67 \mathrm{gh}$ \\
\hline Control & $9.00 \mathrm{a}$ & $7.00 \mathrm{~b}-\mathrm{d}$ & $5.00 \mathrm{ef}$ & $3.00 \mathrm{~g}$ & $1.33 \mathrm{~h}$ \\
\hline
\end{tabular}

Values with the same letters are not significantly different at $\mathrm{P} \leq 0.05$ level; Tukey's multiple range test.

As for the interaction between the tested postharvest treatments and storage period, data in Tables (3\&4) showed that there were significant differences during storage period and shelf life condition. Cantaloupe fruits soaked in chitosan at 2000 ppm and packed with $5 \mathrm{~g}$ potassium permanganate did not exhibit any changes in their appearance till 14 days at $5^{\circ} \mathrm{C}$ plus 2 days at $10^{\circ} \mathrm{C}$ and showed good appearance after 21 days at $5^{\circ} \mathrm{C}$ plus 2 days at $10^{\circ} \mathrm{C}$, mean while fruits soaked in chitosan at $1000 \mathrm{ppm}$ and packed with $2.5 \mathrm{~g}$ potassium permanganate showed good appearance after 14 days at $5^{\circ} \mathrm{C}$ plus 2 days at $10^{\circ} \mathrm{C}$ and dropped to poor level at the end of the shelf life.

\section{3- Fruit firmness}

Data in Figs (5\&6) show that significant reduction in fruit firmness had occurred by prolongation of the storage period. These results were true in the two seasons and in agreement with those of Atress and Attia (2011) on cantaloupe. The decrease in fruit firmness may be due to gradual breakdown of protopectin to lower molecular weight fractions which are more soluble in water and this is directly correlated with the rate of softening of the fruits (Wills et al., 1981). Deterioration in the cell structures and the composition of cell wall causes the fruit softening (Seymour et al., 1993).

Concerning effect of used postharvest treatments, data in Figs (7\&8) revealed that all treatments had significant effect on fruit firmness during storage and shelf life. Cantaloupe fruits soaked in chitosan at 2000 ppm followed by chitosan at 1000 ppm 
or packed with $5 \mathrm{~g}$ potassium permanganate gave the highest value of fruit firmness during storage and shelf life. Fruits soaked in chitosan at $2000 \mathrm{ppm}$ were the best treatment in reducing fruit firmness loss during storage and shelf life in the two seasons. However, the other treatments were less effective in this concern. The lowest value of fruit firmness was obtained from control. These results were in agreement with those of Hong et al. (2012) for chitosan and with Hao and Hao (1993) for potassium permanganate.

$1^{\text {st }}$ season

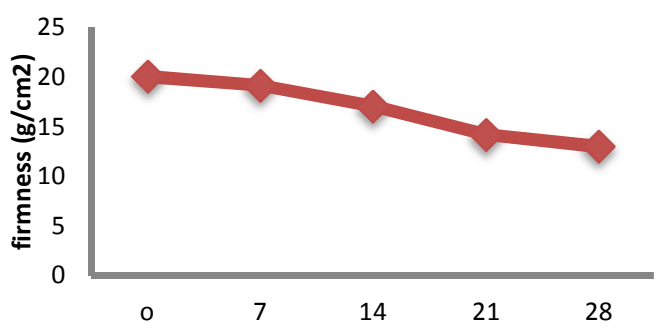

$2 \stackrel{\text { nd }}{\text { season }}$

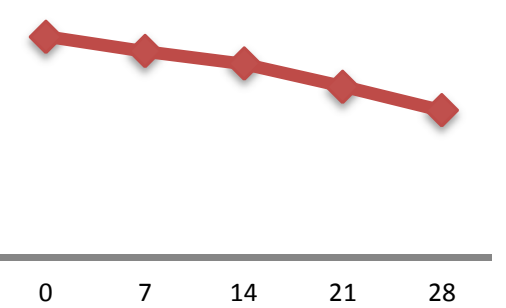

Storage period (day)

Fig. 5. Effect of storage period on firmness $\left(\mathrm{g} / \mathrm{cm}^{2}\right)$ of cantaloupe fruits during storage at $5^{\circ} \mathrm{C}$ and $95 \% \mathrm{RH}$ in 2013 and 2014 seasons.
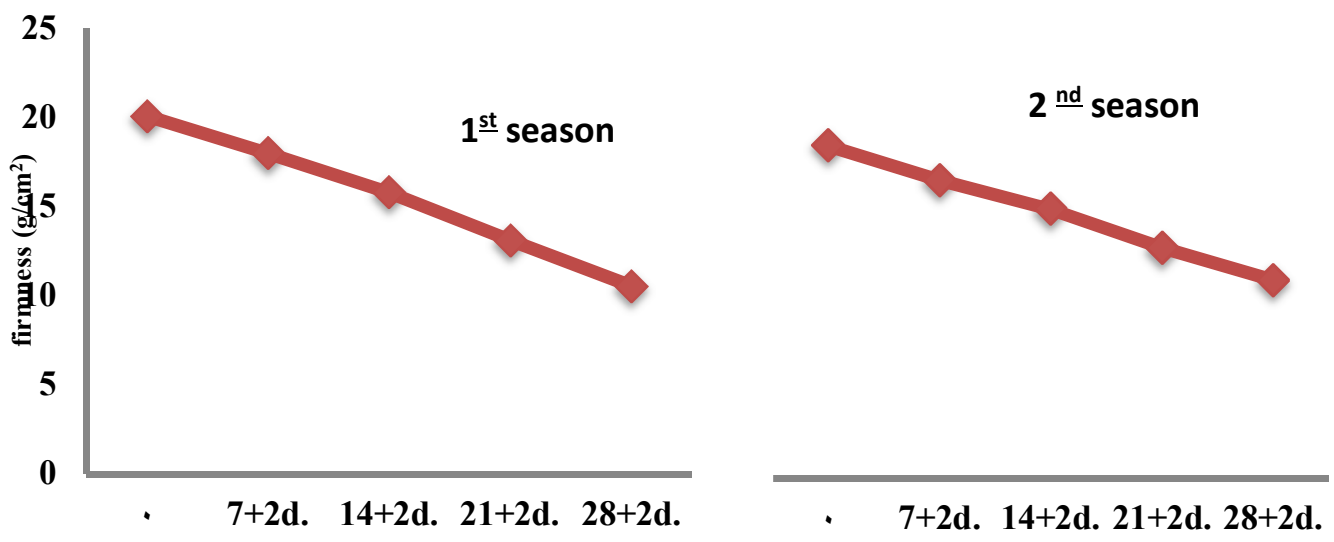

\section{Storage period (day)}

Fig. 6. Effect of storage period on firmness $\left(\mathrm{g} / \mathrm{cm}^{2}\right)$ of cantaloupe fruits during storage at $5^{\circ} \mathrm{C}$ and $95 \%$ RH plus 2 days shelf life at $10^{\circ} \mathrm{C}$ in 2013 and 2014 seasons. 


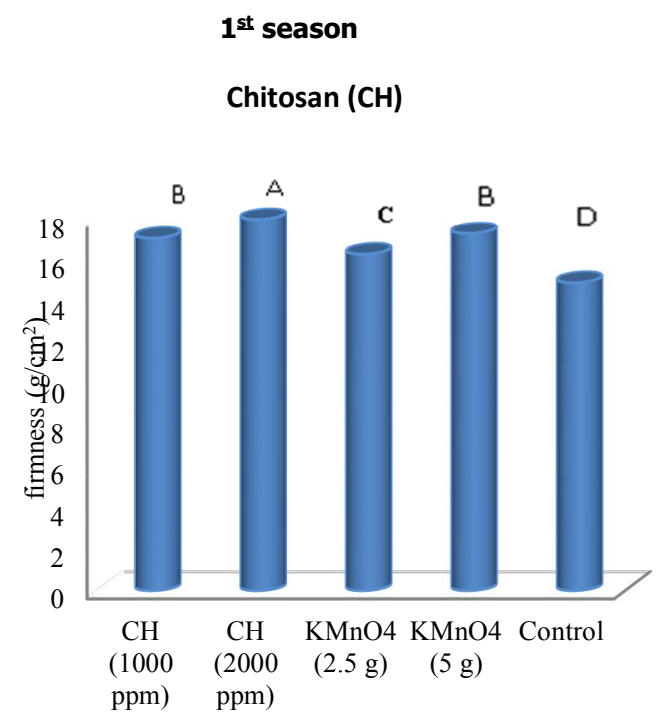

\begin{abstract}
$2^{\text {nd }}$ season
Potassium Permanganate $\left(\mathrm{KMnO}_{4}\right)$
\end{abstract}

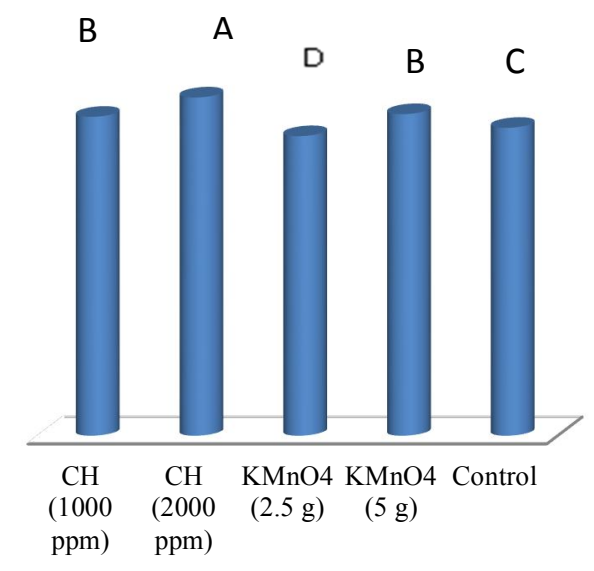

Treatments

Fig.7. Effect of chitosan and potassium permanganate treatments on firmness $\left(\mathrm{g} / \mathrm{cm}^{2}\right)$ of cantaloupe fruits at $5^{\circ} \mathrm{C}$ and $95 \% \mathrm{RH}$ in 2013 and 2014 seasons.

$1^{\text {st }}$ season

Chitosan (CH)

A

B

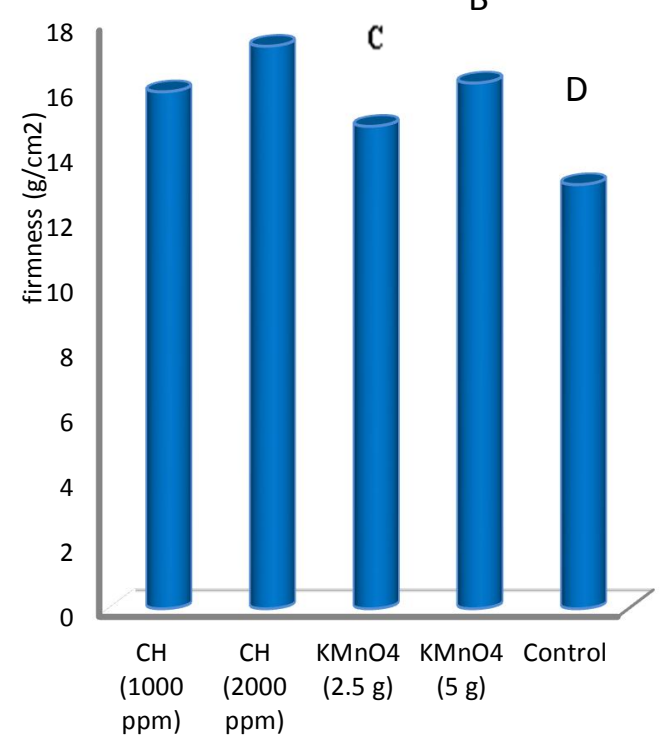

A
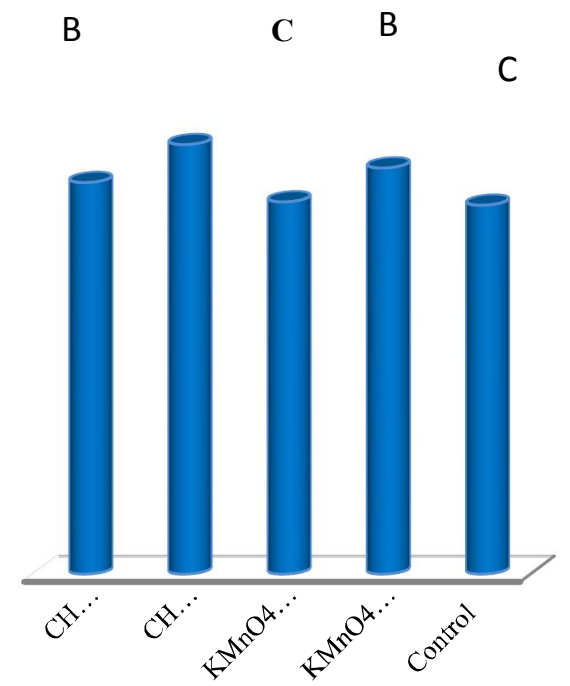

Treatments

Fig. 8. Effect of chitosan and $\mathrm{KMnO}_{4}$ treatments on firmness $\left(\mathrm{g} / \mathrm{cm}^{2}\right)$ of cantaloupe fruits during storage at $5^{\circ} \mathrm{C}$ plus 2 days shelf life at $10^{\circ} \mathrm{C}$ in 2013 and 2014 seasons. 
The favorable effect of chitosan on the maintenance of fruit firmness may be due to the height of antifungal activity and the cover of cuticle and lentical, thereby the infection reduce, respiration and ripening processes during storage as reported by Hong et al. (2012).

In general, the interaction between postharvest treatments (chitosan, potassium permanganate) and storage periods, showed that there were significant differences during

Table 5. Effect of interaction between chitosan, potassium permanganate treatments and storage period on firmness $\left(\mathrm{g} / \mathrm{cm}^{2}\right)$ of cantaloupe fruits during storage at $5^{\circ} \mathrm{C}$ and $95 \% \mathrm{RH}$ in 2013 and 2014 seasons.

\begin{tabular}{|c|c|c|c|c|c|}
\hline \multirow{2}{*}{ Treatments } & \multicolumn{5}{|c|}{ Storage period ( day) } \\
\hline & $\mathbf{0}$ & 7 & 14 & 21 & 28 \\
\hline & \multicolumn{4}{|c|}{ First season (2013) } & \\
\hline Chitosan (1000 ppm) & $20.08 \mathrm{a}$ & $19.46 a b$ & $17.68 \mathrm{~cd}$ & $14.21 \mathrm{f}-\mathrm{h}$ & $13.86 f-h$ \\
\hline Chitosan (2000 ppm) & $20.08 \mathrm{a}$ & $19.83 \mathrm{a}$ & $18.98 \mathrm{a}-\mathrm{c}$ & $16.23 \mathrm{de}$ & $14.65 \mathrm{fg}$ \\
\hline $\mathrm{KMnO}_{4}(2.5 \mathrm{~g})$ & $20.08 \mathrm{a}$ & $18.90 \mathrm{a}-\mathrm{c}$ & $16.21 \mathrm{de}$ & $13.35 \mathrm{~g}-\mathrm{i}$ & $12.87 \mathrm{hi}$ \\
\hline $\mathrm{KMnO}_{4}(5 \mathrm{~g})$ & $20.08 \mathrm{a}$ & $19.50 a b$ & $17.99 \mathrm{bc}$ & 15.19 ef & $13.71 \mathrm{f}-\mathrm{h}$ \\
\hline \multirow[t]{2}{*}{ Control } & $20.08 \mathrm{a}$ & $18.00 \mathrm{bc}$ & $14.42 \mathrm{fg}$ & $12.00 \mathrm{i}$ & $10.00 \mathrm{j}$ \\
\hline & \multicolumn{4}{|c|}{ Second season (2014) } & \\
\hline Chitosan (1000 ppm) & $20.65 a$ & $19.50 a b$ & $18.86 \mathrm{~b}-\mathrm{d}$ & $16.03 \mathrm{~h}-\mathrm{j}$ & $13.22 \mathrm{~lm}$ \\
\hline Chitosan (2000 ppm) & $20.65 \mathrm{a}$ & $19.73 a b$ & $19.20 \mathrm{bc}$ & 17.43 e-h & $16.60 \mathrm{~g}-\mathrm{i}$ \\
\hline $\mathrm{KMnO}_{4}(2.5 \mathrm{~g})$ & $20.65 \mathrm{a}$ & $18.59 \mathrm{~b}-\mathrm{e}$ & $16.69 \mathrm{f}-\mathrm{i}$ & $14.23 \mathrm{kl}$ & $12.76 \mathrm{mn}$ \\
\hline $\mathrm{KMnO}_{4}(5 \mathrm{~g})$ & $20.65 \mathrm{a}$ & $19.60 a b$ & $17.78 \mathrm{~d}-\mathrm{g}$ & $16.26 \mathrm{hi}$ & $14.71 \mathrm{jk}$ \\
\hline Control & $20.65 a$ & $18.00 \mathrm{~b}-\mathrm{d}$ & $15.06 \mathrm{i}$ & $13.99 \mathrm{~m}$ & 10.48 o \\
\hline
\end{tabular}

Values with the same letters are not significantly different at $P \leq 0.05$ level; Tukey's multiple range test.

Table 6. Effect of interaction between chitosan, potassium permanganate treatments and storage period on firmness $\left(\mathrm{g} / \mathrm{cm}^{2}\right)$ of cantaloupe fruits during storage at $5^{\circ} \mathrm{C}$ plus 2 days shelf life at $10^{\circ} \mathrm{C}$ in 2013 and 2014 seasons.

\begin{tabular}{|c|c|c|c|c|c|}
\hline \multirow{2}{*}{ Treatments } & \multicolumn{5}{|c|}{ Storaqe period and shelf life (dav) } \\
\hline & $\mathbf{0}$ & 7+2day & 14+2day & $21+2$ day & $28+2$ days \\
\hline & \multicolumn{4}{|c|}{ First season (2013) } & \\
\hline Chitosan (1000 ppm) & $20.08 \mathrm{a}$ & $18.60 \mathrm{~b}$ & $16.50 \mathrm{de}$ & $12.07 \mathrm{~h}$ & $10.08 \mathrm{ij}$ \\
\hline Chitosan (2000 ppm) & $20.08 \mathrm{a}$ & $19.00 a b$ & $18.00 \mathrm{bc}$ & 15.26 ef & $14.00 \mathrm{fg}$ \\
\hline $\mathrm{KMnO}_{4}(2.5 \mathrm{~g})$ & $20.08 \mathrm{a}$ & $18.31 \mathrm{~b}$ & $15.30 \mathrm{e}$ & $11.25 \mathrm{hi}$ & $9.11 \mathrm{jk}$ \\
\hline $\mathrm{KMnO}_{4}(5 \mathrm{~g})$ & $20.08 a$ & $18.50 \mathrm{~b}$ & $16.80 \mathrm{~cd}$ & $13.72 \mathrm{~g}$ & $11.58 \mathrm{~h}$ \\
\hline \multirow[t]{2}{*}{ Control } & $20.08 \mathrm{a}$ & $15.56 \mathrm{de}$ & $12.40 \mathrm{~h}$ & $9.21 \mathrm{j}$ & $7.86 \mathrm{k}$ \\
\hline & \multicolumn{4}{|c|}{ Second season (2014) } & \\
\hline Chitosan (1000 ppm) & $20.65 a$ & $18.80 \mathrm{ab}$ & $17.00 \mathrm{~b}-\mathrm{d}$ & 13.83 e-h & $11.70 \mathrm{~h}$ \\
\hline Chitosan (2000 ppm) & $20.65 a$ & $19.12 \mathrm{ab}$ & $18.60 a b$ & 16.00 c-e & $15.60 \mathrm{c}-\mathrm{e}$ \\
\hline $\mathrm{KMnO}_{4}(2.5 \mathrm{~g})$ & $20.65 a$ & $17.50 \mathrm{bc}$ & $15.00 \mathrm{~d}-\mathrm{g}$ & $13.00 \mathrm{gh}$ & $11.80 \mathrm{~h}$ \\
\hline $\mathrm{KMnO}_{4}(5 \mathrm{~g})$ & $20.65 a$ & $18.60 \mathrm{ab}$ & $17.00 \mathrm{~b}-\mathrm{d}$ & $15.50 \mathrm{c}-\mathrm{f}$ & $13.26 \mathrm{f}-\mathrm{h}$ \\
\hline Control & $20.65 a$ & $16.46 \mathrm{~cd}$ & $13.90 \mathrm{gh}$ & $11.23 \mathrm{~h}$ & $9.02 \mathrm{i}$ \\
\hline
\end{tabular}

Values with the same letters are not significantly different at $P \leq 0.05$ level; Tukey's multiple range test. 
storage and shelf life in the two seasons. However, cantaloupe fruits soaked in chitosan at 2000 ppm were the most obvious in maintaining fruit firmness at the end of storage period or shelf life.

\section{4- Total soluble solids (TSS)}

Data in Tables (7\&8) indicate that there was a significant reduction in TSS by prolonging of storage period in both seasons. These results agree with those of Atress and Attia (2011) on cantaloupe. The reduction in TSS percent during storage may be due to the higher rate of sugar loss through respiration than the water loss through transpiration (Wills et al., 1981). Regarding the effect of postharvest treatments, data revealed that cantaloupe fruits soaked in chitosan at 2000 ppm retained more TSS percentage with significant differences with the other treatments followed by fruits soaked in chitosan at $1000 \mathrm{ppm}$ or packed with $5 \mathrm{~g}$ potassium permanganate with no significant differences between them in the first season during storage and shelf life in the two seasons.

Table 7. Effect of chitosan and potassium permanganate treatments on TSS (\%) of cantaloupe fruits during storage at $5^{\circ} \mathrm{C}$ and $95 \% \mathrm{RH}$ in 2013 and 2014 seasons.

\begin{tabular}{|c|c|c|c|c|c|c|}
\hline \multirow{2}{*}{ Treatments } & \multicolumn{6}{|c|}{ Storage period (day) } \\
\hline & $\mathbf{0}$ & 7 & 14 & 21 & 28 & Mean \\
\hline \multicolumn{7}{|c|}{ First season (2013) } \\
\hline Chitosan (1000 ppm) & $11.50 \mathrm{a}$ & $11.20 \mathrm{ab}$ & 10.67 a-e & $10.00 \mathrm{~d}-\mathrm{g}$ & $9.74 \mathrm{fg}$ & $10.62 \mathrm{BC}$ \\
\hline Chitosan (2000 ppm) & $11.50 \mathrm{a}$ & $11.33 \mathrm{a}$ & $11.20 \mathrm{ab}$ & 10.67 a-e & $10.33 b-f$ & $11.01 \mathrm{~A}$ \\
\hline $\mathrm{KMnO}_{4}(2.5 \mathrm{~g})$ & $11.50 \mathrm{a}$ & $11.00 \mathrm{a}-\mathrm{c}$ & $10.33 b-f$ & $9.80 \mathrm{e}-\mathrm{g}$ & $9.20 \mathrm{~g}-\mathrm{i}$ & $10.37 \mathrm{C}$ \\
\hline $\mathrm{KMnO}_{4}(5 \mathrm{~g})$ & $11.50 \mathrm{a}$ & $11.00 \mathrm{a}-\mathrm{c}$ & $10.70 \mathrm{a}-\mathrm{d}$ & $10.30 \mathrm{c}-\mathrm{f}$ & 9.80 e-g & 10.66 B \\
\hline Control & $11.50 \mathrm{a}$ & $10.30 \mathrm{c}-\mathrm{f}$ & $9.30 \mathrm{gh}$ & $8.70 \mathrm{hi}$ & $8.33 \mathrm{i}$ & $9.63 \mathrm{D}$ \\
\hline Mean & 11.50 & 10.97 B & $10.44 \mathrm{C}$ & $9.89 \mathrm{D}$ & $9.48 \mathrm{E}$ & \\
\hline \multicolumn{7}{|c|}{ Second season (2014) } \\
\hline Chitosan (1000 ppm) & $11.00 \mathrm{a}$ & $10.50 \mathrm{ab}$ & 10.20 a-e & $10.00 \mathrm{~b}-\mathrm{e}$ & $9.52 \mathrm{c}-\mathrm{g}$ & $10.24 \mathrm{~A}$ \\
\hline Chitosan (2000 ppm) & $11.00 \mathrm{a}$ & $10.67 a b$ & $10.40 \mathrm{a}-\mathrm{c}$ & 10.33 a-d & $10.00 \mathrm{~b}-\mathrm{e}$ & $10.48 \mathrm{~A}$ \\
\hline $\mathrm{KMnO}_{4}(2.5 \mathrm{~g})$ & $11.00 \mathrm{a}$ & $10.67 a b$ & $9.80 \mathrm{~b}-\mathrm{f}$ & $9.40 \mathrm{~d}-\mathrm{g}$ & $8.70 \mathrm{gh}$ & $9.91 \mathrm{~B}$ \\
\hline $\mathrm{KMnO}_{4}(5 \mathrm{~g})$ & $11.00 \mathrm{a}$ & $10.33 \mathrm{a}-\mathrm{d}$ & 10.20 a-e & $10.00 \mathrm{~b}-\mathrm{e}$ & $9.50 \mathrm{c}-\mathrm{g}$ & $10.21 \mathrm{AB}$ \\
\hline Control & $11.00 \mathrm{a}$ & $10.33 \mathrm{a}-\mathrm{d}$ & $9.33 \mathrm{e}-\mathrm{g}$ & $9.00 \mathrm{f}-\mathrm{h}$ & $8.33 \mathrm{~h}$ & $9.60 \mathrm{C}$ \\
\hline Mean & 11.00 & $10.50 \mathrm{~B}$ & $9.99 \mathrm{C}$ & $9.75 \mathrm{C}$ & $9.21 \mathrm{D}$ & \\
\hline
\end{tabular}

Means with the same capital letters in the same column or row are not significantly different at $\mathrm{P} \leq 0.05$ level; Tukey's multiple range test and the small letters for interaction. 
Table 8. Effect of chitosan and potassium permanganate treatments on TSS (\%) of cantaloupe fruits during storage at $5^{\circ} \mathrm{C}$ and $95 \%$ RH plus 2 days shelf life at $10^{\circ} \mathrm{C}$ in 2013 and 2014 seasons.

\begin{tabular}{|c|c|c|c|c|c|c|}
\hline \multirow{2}{*}{ Treatments } & \multicolumn{6}{|c|}{ Storage period and shelf life (day) } \\
\hline & 0 & $7+2$ days & 14+2days & $21+2$ days & $28+2$ days & Mean \\
\hline \multicolumn{7}{|c|}{ First season (2013) } \\
\hline Chitosan (1000 ppm) & $11.50 \mathrm{a}$ & $10.82 \mathrm{a}-\mathrm{d}$ & $10.20 \mathrm{c}-\mathrm{e}$ & 9.74 e-h & $9.20 \mathrm{~g}-\mathrm{j}$ & $10.29 \mathrm{~B}$ \\
\hline Chitosan (2000 ppm) & $11.50 \mathrm{a}$ & $11.30 a b$ & $11.00 \mathrm{a}-\mathrm{c}$ & $10.60 \mathrm{~b}-\mathrm{e}$ & $10.10 \mathrm{~d}-\mathrm{f}$ & $10.86 \mathrm{~A}$ \\
\hline $\mathrm{KMnO}_{4}(2.5 \mathrm{~g})$ & $11.50 \mathrm{a}$ & $10.00 \mathrm{~d}-\mathrm{g}$ & 9.80 e-h & $9.00 \mathrm{~h}-\mathrm{j}$ & $8.40 \mathrm{jk}$ & $9.74 \mathrm{C}$ \\
\hline $\mathrm{KMnO}_{4}(5 \mathrm{~g})$ & $11.50 \mathrm{a}$ & $10.80 \mathrm{a}-\mathrm{d}$ & $10.60 \mathrm{~b}-\mathrm{e}$ & $10.10 \mathrm{~d}-\mathrm{f}$ & $9.30 \mathrm{f}-\mathrm{i}$ & $10.46 \mathrm{~B}$ \\
\hline Control & $11.50 \mathrm{a}$ & $10.10 \mathrm{~d}-\mathrm{f}$ & $9.25 f-j$ & $8.74 \mathrm{i}-\mathrm{k}$ & $7.00 \mathrm{~L}$ & $9.54 \mathrm{D}$ \\
\hline \multirow[t]{2}{*}{ Mean } & $11.50 \mathrm{~A}$ & $10.61 \mathrm{~B}$ & $10.17 \mathrm{C}$ & $9.64 \mathrm{D}$ & $9.02 \mathrm{E}$ & \\
\hline & \multicolumn{5}{|c|}{ Second season (2014) } & \\
\hline Chitosan (1000 ppm) & $11.00 \mathrm{a}$ & $10.11 \mathrm{a}-\mathrm{c}$ & $9.80 \mathrm{~b}-\mathrm{d}$ & $9.32 c-f$ & $8.47 \mathrm{f}-\mathrm{h}$ & 9.74 B \\
\hline Chitosan (2000 ppm) & $11.00 \mathrm{a}$ & $10.50 a b$ & $10.33 a b$ & $10.00 \mathrm{bc}$ & 9.67 b-e & $10.30 \mathrm{~A}$ \\
\hline $\mathrm{KMnO}_{4}(2.5 \mathrm{~g})$ & $11.00 \mathrm{a}$ & $10.33 a b$ & $9.00 \mathrm{~d}-\mathrm{g}$ & $8.21 \mathrm{gh}$ & $7.70 \mathrm{~h}$ & $9.25 \mathrm{C}$ \\
\hline $\mathrm{KMnO}_{4}(5 \mathrm{~g})$ & $11.00 \mathrm{a}$ & $10.20 \mathrm{a}-\mathrm{c}$ & 9.82 b-d & $9.21 \mathrm{c}-\mathrm{f}$ & 8.70 e-g & 9.79 B \\
\hline Control & $11.00 \mathrm{a}$ & $10.00 \mathrm{bc}$ & $9.00 \mathrm{~d}-\mathrm{g}$ & $8.33 \mathrm{f}-\mathrm{h}$ & $7.06 \mathrm{~h}$ & $9.20 \mathrm{D}$ \\
\hline Mean & $11.00 \mathrm{~A}$ & 10.23 B & $9.60 \mathrm{C}$ & $9.01 \mathrm{D}$ & $8.44 \mathrm{E}$ & \\
\hline
\end{tabular}

Means with the same capital letters in the same column or row are not significantly different at $\mathrm{P} \leq 0.05$ level; Tukey's multiple range test and the small letters for interaction.

Control fruits gave the lowest value of TSS percent. These results agree with those of Shiri et al. (2013) for chitosan and Hao and Hao (1993) for potassium permanganate.

Effect of chitosan or potassium permanganate on maintaining TSS of fruits during storage might be due to that these materials reduce respiration rate and physiological changes of fruit during storage.

In general, the interaction between postharvest treatments and storage period was significant, however after 28 days at $5^{\circ} \mathrm{C}$ plus 2 days at $10^{\circ} \mathrm{C}$ of storage, cantaloupe fruits soaked in chitosan at $2000 \mathrm{ppm}$ or packed with $5 \mathrm{~g}$ potassium permanganate resulted in higher TSS content with no significant differences between them, while control fruits gave the lowest ones at the same period.

\section{5- Total sugars}

Data in Tables (9\&10) show that there was a significant reduction in total sugars 
Table 9. Effect of chitosan and potassium permanganate treatments on total sugars (\%) of cantaloupe fruits during storage at $5^{\circ} \mathrm{C}$ and $95 \% \mathrm{RH}$ in 2013 and 2014 seasons.

\begin{tabular}{|c|c|c|c|c|c|c|}
\hline \multirow{2}{*}{ Treatments } & \multicolumn{6}{|c|}{ Storage period (day) } \\
\hline & 0 & 7 & 14 & 21 & 28 & Mean \\
\hline \multicolumn{7}{|c|}{ First season (2013) } \\
\hline Chitosan (1000 ppm) & $9.46 \mathrm{a}$ & $9.28 \mathrm{a}$ & $9.00 a b$ & 8.50 a-d & $7.60 \mathrm{~cd}$ & $8.77 \mathrm{AB}$ \\
\hline Chitosan (2000 ppm) & $9.46 \mathrm{a}$ & $9.30 \mathrm{a}$ & $9.10 a b$ & $8.75 \mathrm{a}-\mathrm{c}$ & $8.00 \mathrm{~b}-\mathrm{d}$ & $8.92 \mathrm{~A}$ \\
\hline $\mathrm{KMnO}_{4}(2.5 \mathrm{~g})$ & $9.46 \mathrm{a}$ & $9.00 \mathrm{ab}$ & $8.47 a-d$ & $8.00 \mathrm{~b}-\mathrm{d}$ & $7.50 \mathrm{~d}$ & 8.49 B \\
\hline $\mathrm{KMnO}_{4}(5 \mathrm{~g})$ & $9.46 \mathrm{a}$ & $9.26 \mathrm{a}$ & $8.85 a b$ & 8.65 a-d & $7.60 \mathrm{~cd}$ & $8.76 \mathrm{AB}$ \\
\hline Control & $9.46 \mathrm{a}$ & $8.85 a b$ & $8.00 \mathrm{~b}-\mathrm{d}$ & $7.50 \mathrm{~d}$ & $6.00 \mathrm{e}$ & $7.96 \mathrm{C}$ \\
\hline \multirow[t]{2}{*}{ Mean } & $9.46 \mathrm{~A}$ & $9.13 \mathrm{~A}$ & 8.68 B & $8.28 \mathrm{C}$ & $7.34 \mathrm{D}$ & \\
\hline & \multicolumn{6}{|c|}{ Second season (2014) } \\
\hline Chitosan (1000 ppm) & $9.80 \mathrm{a}$ & $9.35 b c$ & $9.12 \mathrm{c}-\mathrm{e}$ & $8.55 \mathrm{gh}$ & $7.76 \mathrm{j}$ & 8.92 B \\
\hline Chitosan (2000 ppm) & $9.80 \mathrm{a}$ & $9.50 a b$ & $9.20 \mathrm{~b}-\mathrm{d}$ & $8.87 \mathrm{~d}-\mathrm{g}$ & $7.80 \mathrm{j}$ & $9.03 \mathrm{~A}$ \\
\hline $\mathrm{KMnO}_{4}(2.5 \mathrm{~g})$ & $9.80 \mathrm{a}$ & $9.20 \mathrm{~b}-\mathrm{d}$ & $8.74 \mathrm{fg}$ & $8.24 \mathrm{hi}$ & $7.65 j$ & $8.73 \mathrm{C}$ \\
\hline $\mathrm{KMnO}_{4}(5 \mathrm{~g})$ & $9.80 \mathrm{a}$ & 9.32 bc & $8.90 \mathrm{~d}-\mathrm{f}$ & $8.80 \mathrm{e}-\mathrm{g}$ & $7.85 \mathrm{j}$ & $8.93 \mathrm{AB}$ \\
\hline Control & $9.80 \mathrm{a}$ & $8.90 \mathrm{~d}-\mathrm{f}$ & $8.20 \mathrm{i}$ & $7.56 \mathrm{j}$ & $6.63 k$ & 8.22 D \\
\hline Mean & $9.80 \mathrm{~A}$ & $9.25 \mathrm{~B}$ & $8.83 \mathrm{C}$ & $8.40 \mathrm{D}$ & $7.54 \mathrm{E}$ & \\
\hline
\end{tabular}

Means with the same capital letters in the same column or row are not significantly different at $\mathrm{P} \leq 0.05$ level; Tukey's multiple range test and the small letters for interaction.

by the prolongation of storage period in both seasons. These results are in agreement with those of Atress and Attia (2011) on cantaloupe. The decrease of total sugars percent is probably due to the consumption of sugars through respiration (Wills et al., 1981).

Concerning the effect of postharvest treatments, data revealed that all treatments reduced the loss of total sugars as compared with control.

Table 10. Effect of chitosan and potassium permanganate treatments on total sugars (\%) of cantaloupe fruits during storage at $5^{\circ} \mathrm{C}$ and $95 \% \mathrm{RH}$ plus 2 days shelf life at $10^{\circ} \mathrm{C}$ in 2013 and 2014 seasons.

\begin{tabular}{|c|c|c|c|c|c|c|}
\hline \multirow{2}{*}{ Treatments } & \multicolumn{6}{|c|}{ Storage period and shelf life (day) } \\
\hline & 0 & 7+2days & 14+2days & $21+2$ days & $28+2$ days & Mean \\
\hline \multicolumn{7}{|c|}{ First season (2013) } \\
\hline Chitosan (1000 ppm) & $9.46 a$ & $8.82 \mathrm{a}-\mathrm{c}$ & $8.41 \mathrm{~b}-\mathrm{e}$ & $8.00 \mathrm{c}-\mathrm{g}$ & $7.13 \mathrm{~g}-\mathrm{i}$ & $8.36 \mathrm{AB}$ \\
\hline Chitosan (2000 ppm) & $9.46 a$ & $9.10 a b$ & $8.75 \mathrm{a}-\mathrm{c}$ & $8.32 b-f$ & 7.45 e-h & $8.62 \mathrm{~A}$ \\
\hline $\mathrm{KMnO}_{4}(2.5 \mathrm{~g})$ & $9.46 a$ & $8.74 \mathrm{a}-\mathrm{c}$ & $8.25 b-f$ & $7.40 \mathrm{f}-\mathrm{h}$ & $7.10 \mathrm{~g}-\mathrm{i}$ & 8.19 B \\
\hline $\mathrm{KMnO}_{4}(5 \mathrm{~g})$ & $9.46 \mathrm{a}$ & $9.00 a b$ & $8.60 \mathrm{a}-\mathrm{c}$ & $8.44 b-d$ & $7.25 \mathrm{gh}$ & $8.55 \mathrm{~A}$ \\
\hline Control & $9.46 \mathrm{a}$ & $8.50 \mathrm{a}-\mathrm{d}$ & $7.60 \mathrm{~d}-\mathrm{h}$ & $7.00 \mathrm{hi}$ & $6.27 \mathrm{i}$ & $7.77 \mathrm{C}$ \\
\hline \multirow[t]{2}{*}{ Mean } & $9.46 \mathrm{~A}$ & $8.83 \mathrm{~B}$ & $8.32 \mathrm{C}$ & $7.83 \mathrm{D}$ & $7.04 \mathrm{E}$ & \\
\hline & \multicolumn{5}{|c|}{ Second season (2014) } & \\
\hline Chitosan (1000 ppm) & $9.80 \mathrm{a}$ & $9.00 \mathrm{bc}$ & 8.72 b-e & $8.15 \mathrm{~d}-\mathrm{g}$ & $7.31 \mathrm{hi}$ & $8.60 \mathrm{AB}$ \\
\hline Chitosan (2000 ppm) & $9.80 \mathrm{a}$ & $9.25 a b$ & $8.87 b-d$ & $8.46 b-f$ & $7.54 \mathrm{~g}-\mathrm{i}$ & $8.78 \mathrm{~A}$ \\
\hline $\mathrm{KMnO}_{4}(2.5 \mathrm{~g})$ & $9.80 \mathrm{a}$ & $8.97 \mathrm{bc}$ & $8.39 \mathrm{c}-\mathrm{f}$ & 8.00 e-h & $7.23 \mathrm{hi}$ & 8.48 B \\
\hline $\mathrm{KMnO}_{4}(5 \mathrm{~g})$ & $9.80 \mathrm{a}$ & $9.10 \mathrm{a}-\mathrm{c}$ & 8.76 b-e & $8.67 \mathrm{~b}-\mathrm{e}$ & $7.35 \mathrm{hi}$ & $8.74 A B$ \\
\hline Control & $9.80 \mathrm{a}$ & $8.67 \mathrm{~b}-\mathrm{e}$ & $7.75 \mathrm{f}-\mathrm{i}$ & $7.10 \mathrm{ij}$ & $6.36 j$ & $7.94 \mathrm{C}$ \\
\hline Mean & $9.80 \mathrm{~A}$ & $9.00 \mathrm{~B}$ & $8.50 \mathrm{C}$ & $8.08 \mathrm{D}$ & $7.16 \mathrm{E}$ & \\
\hline
\end{tabular}

Means with the same capital letters in the same column or row are not significantly different at $\mathrm{P} \leq 0.05$ level; Tukey's multiple range test and the small letters for interaction. 
Cantaloupe fruits soaked in chitosan at the two concentrations (1000 and $2000 \mathrm{ppm}$ ) or packed with $5 \mathrm{~g}$ potassium permanganate seems to the most effective in reducing the total sugar losses with no significant differences between them in the first season during storage and in the two seasons during shelf life. These results are in agreement with those of Bautista-Banos et al. (2006) for chitosan and Sammi and Masud (2007) for potassium permanganate.

In general, the interaction between postharvest treatments was significant after 28 days at $5^{\circ} \mathrm{C}$ plus 2 days at $10^{\circ} \mathrm{C}$ of storage. Cantaloupe fruits treated with various treatments had the highest values of total sugars as compared with those of control with no significant differences between them in the second season during storage and in the two seasons during shelf life, while control treatment gave the lowest ones at the same period.

\section{6- Ascorbic acid}

Data in Tables (11\&12) indicate that ascorbic acid content in cantaloupe fruits decreased gradually with the prolongation of storage period and shelf life. These results were true in the two seasons and are in an agreement with those of Atress and Attia (2011) on cantaloupe fruits.

Concerning the effect of postharvest treatments, data show that all treatments were effective in preventing ascorbic acid degradation during storage and shelf life conditions as compared with control. Moreover, cantaloupe fruits soaked in 2000 ppm were the most effective treatment in this concern with significant differences with the other treatments in the second season during storage and in the two seasons during shelf life conditions. The lowest values were noticed in control fruits in both seasons. These results are in agreement with those reported by Hong et al. (2012) for chitosan and Sammi and Masud (2007) for potassium permanganate.

In general, the interaction between postharvest treatments and storage period was significant during all storage periods. All postharvest treatments retained more ascorbic acid content compared to control treatments during all storage periods at $5^{\circ} \mathrm{C}$ or shelf life condition. 
Table 11. Effect of chitosan and potassium permanganate treatments on ascorbic acid (mg/100g F.W) of cantaloupe fruits during storage at $5^{\circ} \mathrm{C}$ and $95 \% \mathrm{RH}$ in 2013 and 2014 seasons.

\begin{tabular}{|c|c|c|c|c|c|c|}
\hline \multirow{2}{*}{ Treatments } & \multicolumn{6}{|c|}{ Storage period (day) } \\
\hline & $\mathbf{0}$ & 7 & 14 & 21 & 28 & Mean \\
\hline \multicolumn{7}{|c|}{ First season (2013) } \\
\hline Chitosan (1000 ppm) & 32.97 a & $31.00 \mathrm{~b}$ & $28.00 \mathrm{~cd}$ & 26.33 ef & $21.90 \mathrm{~h}$ & 28.04 B \\
\hline Chitosan (2000 ppm) & 32.97 a & $31.50 \mathrm{~b}$ & $29.10 \mathrm{C}$ & $27.00 \mathrm{de}$ & $22.00 \mathrm{~h}$ & $28.51 \mathrm{~A}$ \\
\hline $\mathrm{KMnO}_{4}(2.5 \mathrm{~g})$ & 32.97 a & $29.00 \mathrm{C}$ & $27.17 \mathrm{de}$ & 26.00 ef & $21.00 \mathrm{~h}$ & $27.23 \mathrm{C}$ \\
\hline $\mathrm{KMnO}_{4}(5 \mathrm{~g})$ & 32.97 a & $31.50 \mathrm{~b}$ & $28.60 \mathrm{c}$ & $26.77 \mathrm{de}$ & $22.17 \mathrm{~h}$ & $28.40 \mathrm{AB}$ \\
\hline Control & 32.97 a & $25.21 \mathrm{f}$ & $23.60 \mathrm{~g}$ & $18.00 \mathrm{i}$ & $15.55 \mathrm{j}$ & 23.07 D \\
\hline \multirow[t]{2}{*}{ Mean } & $32.97 \mathrm{~A}$ & 29.64 B & $27.29 \mathrm{C}$ & 24.82 D & $20.52 \mathrm{E}$ & \\
\hline & \multicolumn{5}{|c|}{ Second season (2014) } & \\
\hline Chitosan (1000 ppm) & 28.15 a & $26.30 \mathrm{bc}$ & $24.25 \mathrm{de}$ & $22.75 \mathrm{fg}$ & $18.00 \mathrm{i}$ & $23.89 \mathrm{C}$ \\
\hline Chitosan (2000 ppm) & 28.15 a & $27.10 a b$ & $25.10 \mathrm{~cd}$ & 23.00 ef & $22.50 \mathrm{fg}$ & 25.17 A \\
\hline $\mathrm{KMnO}_{4}(2.5 \mathrm{~g})$ & $28.15 \mathrm{a}$ & $26.05 \mathrm{bc}$ & 24.25 de & $21.50 \mathrm{~g}$ & $18.00 \mathrm{i}$ & $23.59 \mathrm{C}$ \\
\hline $\mathrm{KMnO}_{4}(5 \mathrm{~g})$ & $28.15 \mathrm{a}$ & $27.00 a b$ & $25.00 \mathrm{~cd}$ & $22.37 \mathrm{fg}$ & $19.50 \mathrm{~h}$ & 24.40 B \\
\hline Control & $28.15 \mathrm{a}$ & $25.00 \mathrm{~cd}$ & $22.60 \mathrm{fg}$ & $19.00 \mathrm{hi}$ & $15.00 \mathrm{j}$ & 21.95 D \\
\hline Mean & $28.15 \mathrm{~A}$ & 26.29 B & 24.24 C & 21.72 D & $18.60 \mathrm{E}$ & \\
\hline
\end{tabular}

Means with the same capital letters in the same column or row are not significantly different at $P \leq 0.05$ level; Tukey's multiple range test and the small letters for interaction.

Table 12. Effect of chitosan and potassium permanganate treatments on ascorbic acid (mg/100g F.W) of cantaloupe fruits during storage at $5^{\circ} \mathrm{C}$ and $95 \% \mathrm{RH}$ plus 2 days shelf life at $10^{\circ} \mathrm{C}$ in 2013 and 2014 seasons.

\begin{tabular}{|c|c|c|c|c|c|c|}
\hline \multirow{2}{*}{ Treatments } & \multicolumn{6}{|c|}{ Storage period and shelf life (day) } \\
\hline & $\mathbf{0}$ & 7+2days & 14+2days & $21+2$ days & $28+2$ days & Mean \\
\hline \multicolumn{7}{|c|}{ First season (2013) } \\
\hline Chitosan (1000 ppm) & 32.97 a & $26.80 \mathrm{c}$ & $23.53 \mathrm{f}$ & $18.13 \mathrm{jk}$ & $14.90 \mathrm{Im}$ & $23.26 \mathrm{~B}$ \\
\hline Chitosan (2000 ppm) & 32.97 a & $29.30 \mathrm{~b}$ & 25.30 de & $19.33 \mathrm{hi}$ & $15.00 \mathrm{~lm}$ & $24.38 \mathrm{~A}$ \\
\hline $\mathrm{KMnO}_{4}(2.5 \mathrm{~g})$ & 32.97 a & $25.13 \mathrm{e}$ & $22.18 \mathrm{~g}$ & $19.00 \mathrm{~h}-\mathrm{j}$ & $14.00 \mathrm{mn}$ & $22.66 \mathrm{C}$ \\
\hline $\mathrm{KMnO}_{4}(5 \mathrm{~g})$ & 32.97 a & $26.30 \mathrm{~cd}$ & $24.80 \mathrm{e}$ & $18.25 \mathrm{i}-\mathrm{k}$ & $15.50 \mathrm{I}$ & $23.56 \mathrm{~B}$ \\
\hline Control & 32.97 a & $23.21 \mathrm{fg}$ & $20.00 \mathrm{~h}$ & $17.75 \mathrm{k}$ & $13.00 n$ & $21.39 \mathrm{D}$ \\
\hline Mean & $32.97 \mathrm{~A}$ & 26.14 B & $23.16 \mathrm{C}$ & $18.49 \mathrm{D}$ & $14.48 \mathrm{E}$ & \\
\hline \multicolumn{7}{|c|}{ Second season (2014) } \\
\hline Chitosan (1000 ppm) & $28.15 \mathrm{a}$ & $27.75 \mathrm{a}$ & $24.30 \mathrm{bc}$ & $19.75 \mathrm{e}$ & 14.90 hi & 22.97 B \\
\hline Chitosan (2000 ppm) & $28.15 \mathrm{a}$ & $27.90 \mathrm{a}$ & $23.72 \mathrm{c}$ & $21.00 \mathrm{~d}$ & $18.49 \mathrm{f}$ & $23.86 \mathrm{~A}$ \\
\hline $\mathrm{KMnO}_{4}(2.5 \mathrm{~g})$ & $28.15 \mathrm{a}$ & $25.39 \mathrm{~b}$ & $23.18 \mathrm{c}$ & $20.57 \mathrm{de}$ & $14.50 \mathrm{i}$ & $22.36 \mathrm{C}$ \\
\hline $\mathrm{KMnO}_{4}(5 \mathrm{~g})$ & $28.15 \mathrm{a}$ & $26.93 \mathrm{a}$ & $23.25 \mathrm{c}$ & 19.52 ef & $14.30 \mathrm{~g}$ & 22.83B \\
\hline Control & $28.15 \mathrm{a}$ & $24.00 \mathrm{c}$ & 19.70 ef & $16.00 \mathrm{gh}$ & $10.80 \mathrm{j}$ & $19.66 \mathrm{D}$ \\
\hline Mean & $28.15 \mathrm{~A}$ & 26.39 B & $22.83 \mathrm{C}$ & 19.37 D & $14.93 \mathrm{E}$ & \\
\hline
\end{tabular}

Means with the same capital letters in the same column or row are not significantly different at $P \leq 0.05$ level; Tukey's multiple range test and the small letters for interaction. 


\section{CONCLUSION}

From the previous results, it could be concluded that cantaloupe fruits soaked for three minutes in chitosan at $2000 \mathrm{ppm}$ or packed with $5 \mathrm{~g}$ potassium permanganate were the most effective treatments in reducing weight loss, color changes and maintained quality (firmness, total sugars, flavor) and gave fruits with good appearance after 21 days at $5^{\circ} \mathrm{C}$ plus 2 days at $10^{\circ} \mathrm{C}$.

\section{REFERENCES}

1. Akbari, H. and M. Rahemi. 2004. Effect of potassium permanganate on quince fruit storability. M.Sc. Thesis, Shiraz University, Iran.

2. AOAC. 1990. Official Methods of Analysis .13th Ed. Association of Official Analytical Chemists Washington DC. USA.

3. AOAC. 2000. Association of Official Analytical Chemists.Washington DC. USA. International 17th Edition, Revision I.

4. Atress, Amal S. H. and M. M. Attia. 2011. Effect of 1-methylcyclopropene and hot water treatments on retarding ripeness of cantaloupe fruits during cold storage. Egypt. J. Agric. Res., 89 (3): 1089-1103.

5. Bautista-Banos S.; A. N. Hernandez-Lauzardo; M. G. Velazquez-del Valle; M. Hernandez-Lopez; E. A. Barka; E. Bosquez-Molina and C. L. Wilson. 2006. Chitosan as a potential natural compound to control pre and postharvest diseases of horticultural commodities. Crop Protection, 25: 108-118.

6. Chong, J. X.; L. Shaojuan and Y. Hongshun. 2015. Chitosan combined with calcium chloride impacts fresh-cut honeydew melon by stabilizing nanostructures of sodium-carbonate-soluble pectin. Food Control, 53: 195-205.

7. Fallik, E.; S. Alkali-Tuvia; A. Copel; V. Y. Aharoni; D. Ulrich and H. Schulz. 2001. Characterization of Galia melon aroma by GC and mass spectrometric sensor measurement after prolonged storage. Postharvest Biol. Technol., 22: 85-91.

8. Fard, K. G.; K. M. Ghasemnezhad and R. F. Ghazvini. 2010. Effect of chitosan coating on weight loss and postharvest quality of green pepper (Capsicum annum L.) fruits. Acta Hort., 877: 821-826.

9. Hao, H. P. and L. Hao. 1993. Study on storing strawberry at a temperature near the freezing point of water. Journal of Fruit Science, 10:21-24.

10. Hernandez-Munoz, P.; E. Almenar; V. Del; Valle, D. Velez and R. Gavara. 2008. Effect of chitosan coating combined with postharvest calcium treatment on strawberry (Fragaria ananassa) quality during refrigerated storage. Food Chem., 110: 428-435. 
11. Hong, K.; X. Jianghui; Z. Lubin; S. Dequan and G. Deqiang. 2012. Effects of chitosan coating on postharvest life and quality of guava ( Psidium guajava L.) fruit during cold storage. Scientia Horticulturae, 144:172-178.

12. Hussein, Neama M.; M. M. F. AbdAllah; A. Abou El-Yazied and Rawia E. brahim. 2015. Sweet Pepper Quality Maintenance: Impact of hot water and chitosan. Egypt. Hort., 42 (1): $471-491$.

13. Kader, A. A.; W. J. Lipton and L. L. Morris. 1973. Systems for scoring quality of harvested lettuce, HortScience, 8: 408-409.

14. Klein, J.D. and S. lurie. 1992. Pre storage heating of apple fruit for enhanced postharvest quality interaction of time and temperature. Horticultural Science, 27(4) 326-328.

15. Raymond, L. V.; M. Zhang and S. M. R. Azam. 2012. Effect of chitosan coating on physical and microbial characteristics of fresh-cut green peppers (Capsicum annuum L.) Pakistan Journal of Nutrition, 11 (10): 904-909.

16. REID, M.S. 1985. Product maturation and maturity indices. In Postharvest Technology Of Horticultural Crops, Crop. Ext. Univ. California. Div. Agric. Nat. Res. Spec. Public. 3311, 8-11.

17. Sammi, S. and T. Masud. 2007. Effect of different packaging systems on storage life and quality of tomato (lycopersicon esculentum var. rio grande) during different ripening stages. Internet Journal of Food Safety, 9: 37-44.

18. Sardabi, F.; J. Mohtadinia; F. Shavakhi and A. Jafari. 2013. The effects of 1methylcyclopropen (1-mcp) and potassium permanganate coated zeolite nanoparticles on shelf life extension and quality loss of golden delicious apples. Journal of Food Processing and Preservation, 38: 2176-2182.

19. Seymour, G. B.; J. Taylor and G. Tucker. 1993. Biochemistry of fruit ripening.banana. Pp. 83-106. In. Chapman and Hall, London.

20. Shiri, M. A.; D. Bakhshi; M. Ghasemnezhad; M. Dadi; A. Papachatzism and H. Kalorizou. 2013. Chitosan coating improves the shelf life and postharvest quality of table grape (Vitis vinifera) cultivar Shahroudi. Turk J. Agric., 37: 148-156.

21. Snedecor, G. W. and W. G. Cochran. 1982. Statistical methods, 7th Ed., Lowa State Univ. Ames. Iowa USA

22. Watada, A. E. and L. Qi. 1999. Quality of fresh cut produce. Postharvest Biol. Technol., 15(3):201-205.

23. Wills, R. B. H.; T. H. Lee; D. Grahum; W. B. McGlasson and E. G. Hall. 1981. Postharvest, an introduction to physiology and handling of fruits and vegetables. Inc. Westport, Connectiut, USA. 


\title{
تأثير المعاملة بالثيتوزان وبرمنجنات البوتاسيوم على الجودة و القرة التخزينية لثمار الكنتالوب الثبوني
}

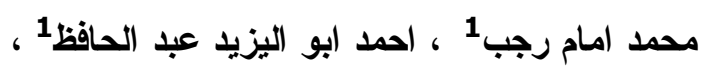

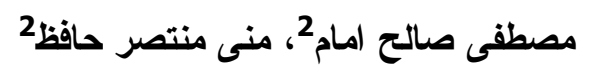

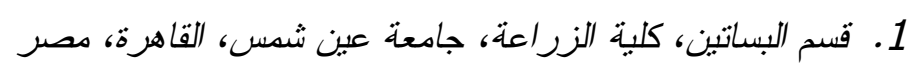

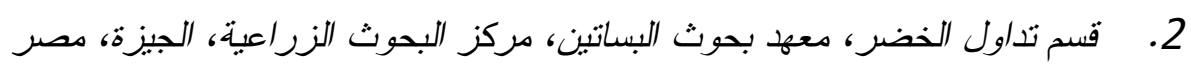

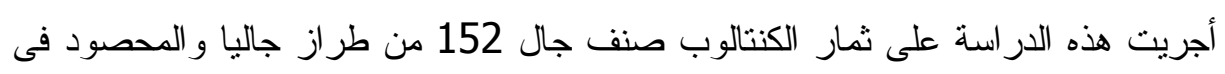

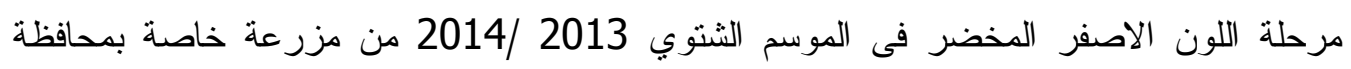

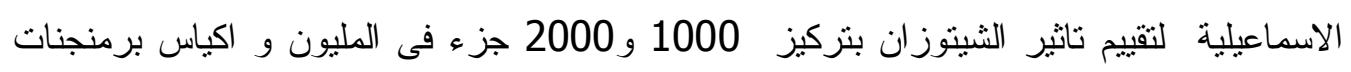

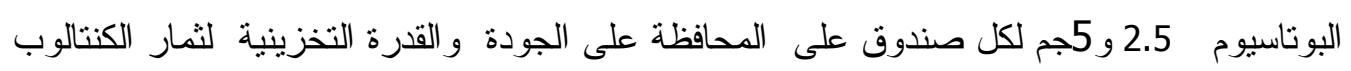

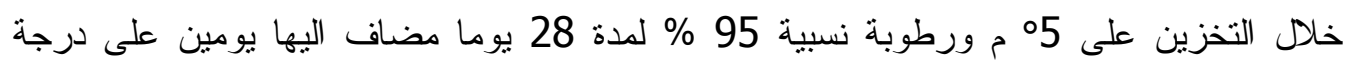

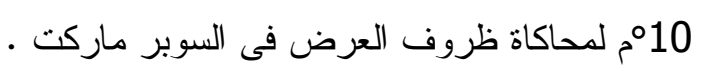

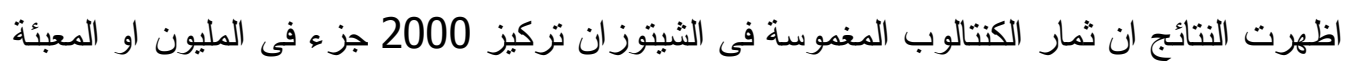

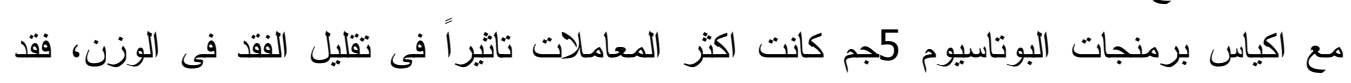

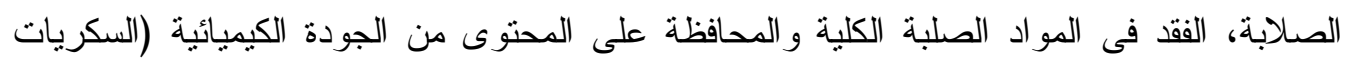

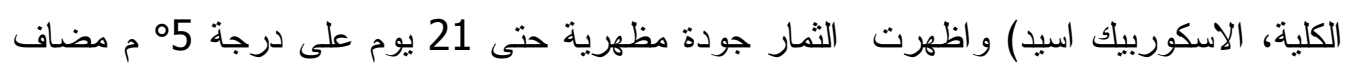

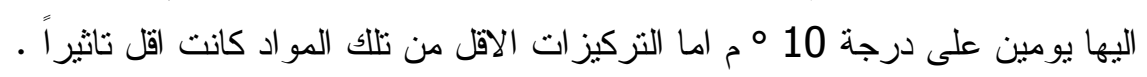

